\title{
Pengaruh Intervensi SEFT (Spiritual Emotional Freedom Technique) terhadap Penurunan Tingkat Depresi Ibu Rumah Tangga dengan HIV
}

\author{
Reini Astuti'1, Iyus Yosep², Raini Diah Susanti ${ }^{2}$ \\ ${ }^{1}$ STIkes Budi Luhur, ${ }^{2}$ Fakultas Keperawatan Universitas Padjadjaran \\ E-mail: reini.ast@gmail.com
}

\begin{abstract}
Abstrak
Depresi adalah kondisi psikiatrik yang sering terjadi pada pasien dengan HIV, hal tersebut sangat mempengaruhi kualitas hidup penderitanya. Dampak ini akan lebih buruk jika terjadi pada ibu rumah tangga, karena mereka bukan merupakan populasi resiko. SEFT (Spiritual Emotional Freedom Technique) diduga dapat menjadi salah satu terapi komplementer yang membantu menurunkan tingkat depresi pada ibu rumahtangga dengan HIV, karena SEFT merupakan penggabungan antara sistem kerja energy psychology dengan kekuatan spiritual sehingga memiliki efek berlipat ganda. Penelitian ini bertujuan untuk mengetahui pengaruh intervensi SEFT terhadap penurunan tingkat depresi pada ibu rumah tangga dengan HIV, karena itu digunakan metode quasiexperimental dengan pre test and post test design. Responden yang sesuai dengan kriteria inklusi dibagi menjadi dua kelompok, yaitu kelompok intervensi $(\mathrm{n}=15)$ dan kelompok kontrol $(\mathrm{n}=15)$. Masing-masing kelompok diukur tingkat depresinya dengan menggunakan BDI (Beck Depression Invantory). Hasil penelitian ini menunjukkan bahwa nilai mean pada kelompok intervensi sebelum diberikan intervensi adalah 24,00 dengan standar deviasi 6,325, setelah dilakukan intervensi menjadi 12,8 dengan standar deviasi 6,327. Perbedaan skor kelompok intervensi pada pre dan post test adalah 11,2 dengan standar deviasi 6,178. Data tersebut terdistribusi dengan normal sehingga uji statistik yang digunakan adalah uji t berpasangan dengan hasil nilai $\mathrm{p}<0,05$. Kesimpulan dari penelitian ini adalah terdapat perbedaan tingkat depresi ibu rumah tangga dengan HIV secara signifikan, setelah dilakukan intervensi SEFT. SEFT dapat direkomendasikan sebagai salah satu terapi komplementer dalam memberikan asuhan keperawatan pada ibu rumah tangga dengan HIV yang mengalami depresi.
\end{abstract}

Kata kunci: Depresi, ibu rumah tangga, HIV, SEFT

\section{Effect of Intervention Spiritual Emotional Freedom Technique toward Decrease The Level of Depression Housewife with HIV}

\begin{abstract}
Depression is a psychiatric condition that often occurs in patients with HIV, it greatly effects the quality of life of sufferers. This impact would be worse if it happens to housewives, because they are not a risk populations. SEFT (Spiritual Emotional Freedom Technique) could be expected to be one of the complementary therapies that help reduce depression of housewives with HIV, because it is a merger between systems of energy psychology with spiritual powers that have the effect of doubling. This study aimed to determine the effect of SEFT interventions in decreasing the level of depression housewives with HIV. This Quasi-experimental study method with pre-test and post-test design. Respondents who fit the inclusion criteria were divided into two groups: the intervention group $(\mathrm{n}=15)$ and control group $(\mathrm{n}=15)$. Each group measured levels of depression using the BDI (Beck Depression Invantory). The results of this study showed that the mean value of the intervention group before given intervention is 24.00 with a standard deviation of 6.325, after the intervention to 12.8 with a standard deviation of 6.327. Differences in the intervention group scores on the pre and post test was 11.2 with a standard deviation of 6.178. The data was normally distributed so that the statistical test used is paired $t$ test with the results of the value of $p<0.05$. The conclusion from this study was that there are differences in the level of depression housewife with HIV significantly, after the intervention SEFT. SEFT can be recommended as a complementary therapy in providing nursing care of housewives with HIV who are depressed.
\end{abstract}

Key words: Depression, housewives, HIV, SEFT 
Reini Astuti: Pengaruh Intervensi SEFT terhadap Penurunan Tingkat Depresi Ibu Rumah Tangga

\section{Pendahuluan}

AcquiredImmunodeficiencySyndrome(AIDS) merupakan kumpulan gejala dan infeksi atau sindrom yang timbul akibat rusaknya sistem kekebalan di dalam tubuh manusia akibat infeksi virus HIV. Virus penyebab penyakit dinamakan Human Immunodeficiency Virus (atau disingkat HIV). Virus ini bekerja dengan memperlemah sistem kekebalan tubuh manusia, sehingga orang yang terkena virus ini akan rentan terhadap infeksi opportunity. Infeksi opportunity adalah infeksi yang disebabkan oleh organisme yang biasanya tidak menyebabkan penyakit pada orang dengan sistem kekebalan tubuh yang normal, tetapi dapat menyerang orang dengan sistem kekebalan tubuh yang buruk. Mereka membutuhkan "kesempatan" untuk menginfeksi seseorang. HIV tidak dapat disembuhkan, obat-obatan hanya dapat memperlambat laju perkembangan virus (Ditjen PP\&PL 2012; Kemenkes 2012).

Tahun 1981 penyakit HIV pertama kali ditemukan. UNAIDS dan WHO memperkirakan bahwa penyakit ini telah membunuh lebih dari 25 juta jiwa, sehingga penyakit ini merupakan salah satu epidemik paling menghancurkan di sepanjang sejarah peradaban manusia. WHO memperkirakan bahwa terdapat lebih dari 33 juta orang terinfeksi HIV di seluruh dunia. Kejadian penyakit ini di negara berkembang sekitar 90\% dari jumlah keseluruhan. HIV mengakibatkan kematian 3,2 juta jiwa dan setiap harinya 1800 anak (sebagian besar bayi baru lahir) terinfeksi HIV (Ditjen PP\&PL 2012; Kemenkes 2012).

Pola penularan HIV di Indonesia didominasi oleh orang yang berhubungan seks heteroseksual bukan homoseksual seperti yang menjadi stigma selama ini, sehingga kelompok ini mendominasi penyebaran HIV di Indonesia dan akhirnya penyakit ini dapat mengenai siapa saja. Perkembangan terakhir ini ditemukan kasus HIV pada kelompok ibu rumah tangga yang tidak memiliki perilaku berisiko tinggi dan hanya berhubungan seksual dengan suaminya (Kemenkes, 2010).

Awal ditemukannya yaitu tahun 1987 sampai dengan 1997, penularan HIV-AIDS didominasi oleh populasi berisiko kaum homoseksual. Tahun 1997 sampai 2007, penularan HIV/AIDS didominasi oleh populasi berisiko IDU (Injections Drugs Use). Tahun 2007 sampai sekarang penularan didominasi oleh pelaku seks heteroseksual, yaitu laki-laki yang melakukan hubungan seksual dengan wanita pekerja. Akibatnya penularan HIV kini berkembang melalui hubungan seksual antara pelanggan pekerja seksual dan pasangan resminya (istrinya) dan dari ibu ke anaknya (KPA Nasional, 2009 ). Sementara Komisi Penanggulangan AIDS Provinsi Jawa Barat mencatat jumlah ibu rumah tangga yang tertular HIV sejak 2006 hingga 2012 sebanyak 763 orang (KPA Jawa Barat, 2013).

Kota Bandung merupakan kota dengan angka kasus HIV/AIDS tertinggi di Jawa Barat. Sejak tahun 2006 kasus HIV mulai ditemukan pada ibu rumah tangga dan terjadi pula peningkatan jumlah kasus HIV/AIDS pada ibu rumah tangga sebesar 2,8 \% dari tahun 2009 sampai 2011. Jumlah komulatif penderita HIV/ AIDS di Kota Bandung adalah 3114, dengan jumlah penderita pada ibu rumah tangga secara komulatif adalah 338 orang atau sebanyak 10,85\%. Angka ini lebih tinggi jika dibandingkan dengan populasi risiko wanita pekerja seksual yang hanya mencapai 4,05\% (KPA Kota Bandung, 2014). Jumlah total ibu rumah tangga dengan HIV di Jawa Barat 44,3 \% nya berada di kota Bandung.

Ibu rumah tangga bukan merupakan populasi berisiko terkena HIV/AIDS, hal ini akan lebih memperberat kondisi psikis mereka ketika mereka menerima vonis terkena HIV/AIDS. Rasa malu, takut adanya penolakan dan stigma bahwa penyakit HIV berasal dari perilaku yang buruk, membuat seseorang yang terkena penyakit tersebut merasa terasing dan menimbulkan dampak psikologi yang hebat (Pohan, 2006 ; Fernandez dan Ruiz, 2006). HIV tidak hanya berdampak kepada kondisi fisik, akan tetapi sangat mempengaruhi kondisi psikiatrik seseorang yang menderitanya.

Depresi adalah kondisi psikiatrik yang banyak terjadi pada pasien dengan HIV (Candra, Desai dan Ranjan, 2005) . Kondisi tersebut sangat mempengaruhi quality of life bagi penderitanya (Pohan, 2006). Bahkan bagi sebagian mereka ada yang ingin melakukan bunuh diri ( Fernandez dan Ruiz, 
Reini Astuti: Pengaruh Intervensi SEFT terhadap Penurunan Tingkat Depresi Ibu Rumah Tangga

2006; Hawari 2006). Kecemasan dan depresi menjadi salah satu penyebab terjadinya bunuh diri dan berdampak pada peningkatan angka bunuh diri. Diperkirakan 5\% sampai $15 \%$ dari orang-orang yang terkena depresi melakukan bunuh diri setiap tahunnya (Katzenstein, 1998 dalam Hawari, 2006).

Depresi yang tidak tertanggulangi dengan baik dapat menurunkan sistim imunitas penderita HIV (Nursalam dan Kurniawati, 2011 ; Alemu, Mariam,Tsui, Ahmed , Shewamare, 2011). Keadaan depresi dapat menurunkan fungsi imun, fungsi selsel“natular killer” dan reaksi lymphocyte sehingga berkontribusi pada percepatan penurunan jumlah CD4 penderitanya, dengan demikian kemungkinan infeksi opportunity lebih tinggi (Burack, Barrett, \& Stall, 1993). Depresi juga dapat memperburuk kondisi kesehatan penderita HIV (Ironson, Balbin, Stuetzle, Fletcher, O'Cleirigh, Laurenceau, Schneiderman, Solomon, 2005) karena secara fisiologis HIV menyerang sistim kekebalan tubuhnya. Jika penderitanya juga mengalami depresi maka dapat mempercepat terjadinya AIDS dan meningkatkan kematian (Nursalam dan Kurniawati, 2011). Penderita HIV yang mengalami depresi rentan terhadap penyakit dua kali lebih sering dibanding penderita HIV yang tidak mengalami depresi (Ironson dkk., 2005). Selain itu keadaan depresi yang dialami oleh penderita HIV dapat memengaruhi ketidakpatuhannya terhadap pengobatan (Carter, 2011).

SEFT merupakan salah satu terapi komplementer yang dapat digunakan untuk menurunkan tingkat depresi. Keefektifan SEFT terletak pada pengabungan antara Spiritual Power dengan Energy Psychology. Spiritual Power memiliki lima prinsip utama yaitu ikhlas, yakin, syukur, sabar dan khusyu. Energy Psychology merupakan seperangkat prinsip dan teknik memanfaatkan sistem energi tubuh untuk memerbaiki kondisi pikiran, emosi dan perilaku (Freinstein dalam Zainudin, 2012 ). Ketidakseimbangan kimia dan gangguan energi dalam tubuh manusia dapat menyebabkan gangguan emosi, termasuk depresi. Intervensi SEFT pada sistim energi tubuh inilah yang dapat mengubah kondisi kimia di dalam otak (neurotransmitter) yang selanjutnya dapat mengubah kondisi emosi seseorang termasuk kondisi depresi. Selain itu SEFT efektif, mudah, cepat, murah, efeknya dapat permanen, tidak terdapat efek samping, bersifat universal, memberdayakan individu (tidak tergantung pada pemberi terapi), dapat dijelaskan secara ilmiah (Zainudin, 2012).

Melihat berbagai hal tersebut di atas, maka penulis berkeinginan untuk melakukan penelitian tentang pengaruh intervensi SEFT terhadap penurunan tingkat depresi, pada ibu rumah tangga dengan HIV. Tujuan penelitian ini untuk mengetahui pengaruh intervensi SEFT (Spiritual Emotional Freedom Technique) terhadap penurunan tingkat depresi pada ibu rumah tangga dengan HIV di Kota Bandung.

\section{Metode Penelitian}

Metode penelitian yang digunakan pada penelitian ini adalah quasi-experimental dengan pretest and posttest design, menggunakan kelompok kontrol untuk dapat menguji adanya sebab dan akibat pada sebuah fenomena. Pemilihan responden penelitian tidak dilakukan secara acak (Polit and Beck, 2006; Supranto, 2000) . Sampel dalam penelitian ini menggunakan teknik non probability sampling dengan metode purposive sampling. Kriteria inklusi penelitian ini, ibu rumah tangga dengan HIV yang beragama Islam, bersedia menjadi responden, dapat membaca dan menulis. Instrumen dalam penelitian ini digunakan untuk mengukur tingkat depresi pada ibu rumah tangga dengan HIV. Alat ukur yang digunakan adalah BDI (Beck Depression Inventory). BDI merupakan alat ukur yang dapat dipercaya untuk mendeteksi ada atau tidaknya depresi secara cepat dan tepat serta dapat memperlihatkan tingkat keparahan penderitanya, dengan skor lebih dari 17 dan kurang dari 40, responden berada dalam rentang usia produktif (18 - 45 tahun, memiliki Insight (kesadaran diri). Kriteria eksklusi dalam penelitian ini adalah ibu rumah tangga dengan HIV yang memiliki keterbatasan pendengaran dan penglihatan (tuna rungu dan tuna netra). Penentuan jumlah sampel dengan menggunakan rumus sebagai berikut: 
Reini Astuti: Pengaruh Intervensi SEFT terhadap Penurunan Tingkat Depresi Ibu Rumah Tangga

Penelitian eksperimen dilakukan untuk mengantisipasi hilangnya unit eksperimen, dilakukan koreksi dengan 1/(1-f), di mana $\mathrm{f}$ adalah proporsi unit eksperimen yang hilang atau mengundurkan diri atau drop out. Penelitian ini terdapat droup out pada kelompok intervensi sebanyak 1 orang pada hari ke 3. Kelompok intervensi menjadi 15 orang, dan agar hasilnya lebih homogen maka kelompok kontrol pun menjadi 15 orang juga.

Setelah mendapatkan persetujuan responden, kemudian dilakukan pengukuran tingkat depresi pada ibu rumah tangga dengan HIV pada kelompok intervensi maupun kelompok kontrol, pada kelompok intervensi diberikan intervensi SEFT (Spiritual Emotional Freedom Technique) sebanyak empat kali. Pada akhir sesi dilakukan pengukuran kembali tingkat depresi pada kelompok intervensi maupun kelompok kontrol.

Penelitian ini menggunakan analisa univariat untuk mengetahui distribusi frekuensi, presentase dari karakteristik responden meliputi usia, status marital, tingkat pendidikan, agama dan lamanya terdiagnosa HIV. Selain karakteristik responden analisis univariat ini bertujuan untuk melihat gambaran karakteristik responden yang mengalami depresi pada responden kelompok intervensi maupun kelompok kontrol. Analisa bivariat dalam penelitian ini dilakukan untuk mengetahui apakah terdapat pengaruh intervensi SEFT terhadap penurunan tingkat depresi.

\section{Hasil Penelitian}

Karakteristik Responden

Tabel 1 menggambarkan bahwa mayoritas responden baik kelompok kontrol dan kelompok intervensi termasuk dalam katagori dewasa madya (29-39 tahun) yaitu sebanyak $56,67 \%$. Sedangkan untuk status pernikahan responden yang berstatus menikah sebanyak 76,67 \%. Status pendidikan, persentase yang terbanyak adalah SMA sebanyak 43,33 \%. Sedangkan untuk lamanya terdiagnosis HIV sebanyak 84,8\% responden menyatakan telah terdiagnosis antara 1-5 tahun.

Tabel 2 memperlihatkan tingkat depresi pada kelompok intervensi dan kelompok kontrol sebelum dilakukan intervensi SEFT (Spiritual Emotional Freedom Technique). Hasilnya menunjukkan bahwa

Tabel 1 Distribusi Frekuensi Responden Berdasarkan Usia, Pendidikan, Status Pernikahan, Agama dan Lamanya Terdiagnosa HIV

\begin{tabular}{|c|c|c|c|c|c|}
\hline No & Variabel & Kontrol & Persentase & Intervensi & Persentase \\
\hline & & $\mathbf{n}$ & & $\mathbf{n}$ & \\
\hline \multirow[t]{4}{*}{1} & Umur responden & & & & \\
\hline & 18-28 tahun (dewasa awal) & 9 & $60 \%$ & 4 & $26,70 \%$ \\
\hline & 29-39 tahun (dewasa madya) & 6 & $40 \%$ & 11 & $73,30 \%$ \\
\hline & 40-49 (dewasa akhir) & & & & \\
\hline \multirow[t]{3}{*}{2} & Status Pernikahan & & & & \\
\hline & Tidak Menikah (janda) & 3 & $20 \%$ & 4 & $26,70 \%$ \\
\hline & Menikah & 12 & $80 \%$ & 11 & $73,30 \%$ \\
\hline \multirow[t]{5}{*}{3} & Tingkat Pendidikan & & & & \\
\hline & SD & & & 1 & $6,70 \%$ \\
\hline & SMP & 2 & $13,33 \%$ & 10 & $66,70 \%$ \\
\hline & SMA & 9 & $60 \%$ & 4 & $26,70 \%$ \\
\hline & PT & 4 & $26,6 \%$ & & \\
\hline \multirow[t]{3}{*}{4} & Lamanya terdiagnosa HIV & & & & \\
\hline & $1-5$ tahun & 14 & $83,33 \%$ & 11 & $73,30 \%$ \\
\hline & 6-10 tahun & 1 & $16,66 \%$ & 4 & $26,70 \%$ \\
\hline
\end{tabular}


Reini Astuti: Pengaruh Intervensi SEFT terhadap Penurunan Tingkat Depresi Ibu Rumah Tangga

pada kelompok intervensi sebanyak 33,3 \% mengalami depresi pada garis batas depresi klinis, kemudian sebanyak $46,7 \%$ mengalami depresi sedang dan $20 \%$ responden mengalami depresi berat. Kelompok kontrol didapatkan data bahwa sebanyak 27,8\% resonden mengalami depresi pada batas klinis. Sedangkan 72,2\%.responden yang mengalami depresi sedang.

Tabel 3 memperlihatkan gambaran tingkat depresi pada kelompok intervensi post test adalah sebagai berikut, sebanyak 33,3\% responden wajar, kemudian sebanyak 53,3\% responden mengalami gangguan mood dan sebanyak 13,3 \% responden mengalami depresi sedang. Kelompok kontrol menunjukkan bahwa tidak ada perubahan yang signifikan dimana hasilnya relatif tetap dengan kondisi pre yaitu sebanyak 27,8\% responden berada dalam garis batas depresi klinis dan $72,2 \%$ responden mengalami depresi sedang. Analisa bivariat dilakukan untuk mengetahui perbedaan skor depresi sebelum dan setelah intervensi SEFT (Spiritual Emotional Freedom Technique).

Tabel 4 menunjukkan bahwa nilai mean pada kelompok intervensi sebelum diberikan intervensi adalah 24,00 dengan standar deviasi 6,325. Nilai mean kelompok intervensi setelah dilakukan intervensi adalah 12,8 dengan standar deviasi 6,327. Perbedaan skor kelompok intervensi pada pre dan post test adalah 11,2. Nilai mean pada kelompok kontrol pada kondisi pre adalah 21,87 dengan standar deviasi 2,446. Nilai mean kelompok kontrol pada kondisi post adalah 23,13 dengan standar deviasi 5,975. Perbedaan rata-rata skornya adalah -1,267.

Data tersebut terdistribusi dengan normal sehingga uji statistik yang digunakan adalah uji t berpasangan dengan hasil nilai $\mathrm{p}<0,05$. Hal ini mengindikasikan bahwa Ho ditolak, artinya bahwa terdapat perbedaan yang signifikan tingkat depresi ibu rumah tangga dengan HIV setelah dilakukan intervensi SEFT (Spiritual Emotional Freedom Technique).

Tabel 5 menunjukkan bahwa nilai mean post test pada kelompok intervensi adalah adalah 11,20 dengan standar deviasi 6,178. Kelompok kontrol menunjukkan nilai mean post test adalah -1,27 dengan standar deviasi nya 5,788. Hasil post test baik kelompok intervensi maupun kelompok

Tabel 2 Distribusi Frekuensi Responden Berdasarkan Tingkatan Depresi pada Kelompok Intervensi dan Kelompok Kontrol Pre Test

\begin{tabular}{|c|c|c|c|c|c|c|c|}
\hline Variabel & Kategori & Frek & $\%$ & Variabel & Kategori & Frek & $\%$ \\
\hline & & (n) & & & & (n) & \\
\hline \multirow[t]{4}{*}{$\begin{array}{l}\text { Kelompok } \\
\text { Intervensi }\end{array}$} & garis batas depresi klinis & 5 & $33,3 \%$ & $\begin{array}{c}\text { Kelompok } \\
\text { Kontrol }\end{array}$ & $\begin{array}{l}\text { garis batas } \\
\text { depresi klinis }\end{array}$ & 5 & $27,8 \%$ \\
\hline & depresi sedang & 7 & $46,7 \%$ & & depresi sedang & 10 & $72,2 \%$ \\
\hline & depresi berat & 3 & $20,0 \%$ & & & & \\
\hline & Total & 15 & $100,0 \%$ & & Total & 15 & $100,0 \%$ \\
\hline
\end{tabular}

Tabel 3 Distribusi Frekuensi Responden Berdasarkan Tingkatan Depresi pada kelompok Intervensi dan Kontrol Post Test

\begin{tabular}{|c|c|c|c|c|c|c|c|}
\hline Variabel & Kategori & Frek & $\%$ & Var & Kategori & Frek & $\%$ \\
\hline & & (n) & & & & (n) & \\
\hline \multirow[t]{4}{*}{$\begin{array}{c}\text { Kelompok } \\
\text { Kontrol }\end{array}$} & wajar & 5 & $33,3 \%$ & $\begin{array}{c}\text { Kelompok } \\
\text { Kontrol }\end{array}$ & & & \\
\hline & $\begin{array}{l}\text { gangguan } \\
\text { mood }\end{array}$ & 8 & $53,3 \%$ & & $\begin{array}{l}\text { garis batas } \\
\text { depresi } \\
\text { klinis }\end{array}$ & 5 & $27,8 \%$ \\
\hline & depresi sedang & 2 & $13,3 \%$ & & $\begin{array}{l}\text { depresi } \\
\text { sedang }\end{array}$ & 10 & $72,2 \%$ \\
\hline & Total & 15 & $100 \%$ & & Total & 15 & $100 \%$ \\
\hline
\end{tabular}


Reini Astuti: Pengaruh Intervensi SEFT terhadap Penurunan Tingkat Depresi Ibu Rumah Tangga

Tabel 4 Perbedaan Rata-Rata Skor Depresi Berdasarkan Kelompok Pre-Post Intervensi dan Pre-Post Kontrol

\begin{tabular}{cccccccc}
\hline Kelompok & Variabel & Mean & N & $\begin{array}{c}\text { Std. } \\
\text { Deviation }\end{array}$ & $\begin{array}{c}\text { Perbedaan } \\
\text { rata-rata }\end{array}$ & t & p Value \\
\hline Intervensi & pre intervensi & 24,00 & 15 & 6,325 & 11,200 & 7,021 &, 000 \\
& pos intervensi & 12,80 & 15 & 6,327 & & & \\
\multirow{2}{*}{ Kontrol } & pre kontrol & 21,87 & 15 & 2,446 & $-1,267$ &,- 848 &, 411 \\
& pos kontrol & 23,13 & 15 & 5,975 & & & \\
\hline
\end{tabular}

Tabel 5 Perbedaan Skor Depresi Berdasarkan Kelompok Post Intervensi dan Post Kontrol

\begin{tabular}{cccccc}
\hline Kelompok & $\mathbf{N}$ & Mean & Std. Deviation & t & p Value \\
\hline Intervensi & 15 & 11,20 & 6,178 & \multirow{2}{*}{5,703} & 0,0001 \\
Kontrol & 15 & $-1,27$ & 5,788 & & \\
\hline
\end{tabular}

kontrol terdistribusi secara normal sehingga uji statistik yang digunakan adalah uji t tidak berpasangan. Hasil uji statistiknya menunjukkan bahwa terdapat nilai $\mathrm{p}<0,05$. Disimpulkan bahwa terdapat perbedaan yang signifikan dari intervensi SEFT pada kelompok intervensi terhadap kelompok kontrol.

\section{Pembahasan}

Karakteristik responden yang diteliti meliputi usia, pekerjaan, pendidikan, agama, suku bangsa, status pernikahan dan lamanya terdiagnosa HIV. Sebagian besar responden adalah ibu rumah tangga pada usia dewasa madya $(56,67 \%)$ dimana usia ini termasuk dalam usia produktif, dengan status menikah (76,67 \%). Seseorang yang telah memasuki usia produktif dituntut peran yang lebih besar, karena bagi sebagian orang, masa ini merupakan puncak dari kesehatan fisik dan kesempatan untuk meninggal karena penyakit cukup kecil. Selain itu pada masa ini kesempatan reproduksi berada pada tingkat tertinggi (Feldman, 2011). Seseorang yang mengalami penyakit kronis pada masa ini apalagi penyakit yang dinyatakan belum dapat disembuhkan seperti HIV, menyebabkan penderita lebih sulit untuk menerima sakitnya. Seringkali wanita dengan HIV harus merawat pasangannya dan atau anaknya yang mengalami penyakit yang sama dan sangat tergantung pada ibunya (Spritia, 2008). Hal ini sesuai dengan penelitian yang dilakukan oleh (Trilistya, 2006), hasil penelitian Trilistya ini menyebutkan bahwa terdapat hubungan yang bermakna antara jenis kelamin dan status pernikahan dimana wanita lebih cenderung mengalami depresi daripada laki-laki dengan perbandingan rasio 2:1. Prevalensi kejadian depresi juga lebih tinggi pada orang yang menikah dibandingkan dengan yang tidak menikah (Trilistya, 2006).

Penelitian yang dilakukan oleh Yaunin dkk (2014) juga menemukan bahwa kejadian depresi banyak terjadi pada penderita HIV dengan status menikah yaitu 50\% dari 24 responden yang diteliti. Penelitian lain yang mendukung dilakukan oleh Unnikrishnan dan kawan-kawan (2012), hasil penelitian ini juga menyebutkan bahwa gangguan depresi yang terbanyak terjadi pada orang dengan status menikah (44,6\%). Hal ini disebabkan karena pada pasien HIV/AIDS yang sudah menikah pada umumnya memiliki banyak kendala dalam kehidupannya seperti permasalahan rumah tangga, permasalahan ekonomi keluarga, ditambah lagi dengan kurangnya dukungan dari keluarga dekat dan lingkungan. Sehingga dapat menyebabkan meningkatnya stress mental pada pasien HIV/AIDS yang apabila tidak ditangani dengan baik, dapat menjadi gangguan depresi (Yaunin; Hidayat, 2014).

Hasil penelitian menunjukkan bahwa ibu rumah tangga dengan HIV mengalami depresi mulai rentang garis batas depresi klinis sampai depresi berat. Kurang lebih 5-10\% masyarakat umum mengalami depresi, namun angka depresi pada penderita HIV dapat mencapai 60\% (Spiritia, 2008). Hal ini didukung oleh penelitian yang dilakukan oleh Darussalam (2011). Hasil penelitian ini menyebutkan bahwa penyakit penyerta yang 
Reini Astuti: Pengaruh Intervensi SEFT terhadap Penurunan Tingkat Depresi Ibu Rumah Tangga

dialami oleh seseorang dapat menyebabkan depresi pada penderitanya. Kaplan (2012) juga menyebutkan bahwa faktor psikososial yang salah satunya adalah penurunan kesehatan dapat menyebabkan depresi.

Depresi merupakan kondisi psikiatrik yang paling banyak ditemui pada penderita HIV (Candra, Desai dan Ranjan, 2005) angkanya dapat mencapai 33-50\%, hal ini sangat tergantung pada kriteria diagnostik yang digunakan (Ciesla \& Roberts, 2001). Penelitian yang dilakukan oleh Pyne, dkk., (2007) dan Ofovwe (2013) yang dilakukan pada 113 responden, menemukan bahwa penderita HIV memiliki risiko lebih tinggi untuk mengalami depresi. Bahkan diperkirakan penderita HIV positif memiliki risiko dua sampai lima kali lebih tinggi dibandingkan dengan orang-orang dengan HIV negatif. Wanita memiliki kemungkinan dua kali lebih besar untuk mengalami depresi dibandingkan dengan pria. Kurang lebih seperempat dari seluruh wanita cenderung mengalami depresi pada saat yang sama dalam kehidupan mereka (Feldman, 2011). Apalagi jika yang mengalaminya adalah ibu rumah tangga yang terkena HIV. Ibu rumah tangga bukan merupakan populasi yang memiliki perilaku berisiko. Mereka hanya melakukan hubungan dengan pasangannya, tidak mengenal narkoba, tetapi tiba-tiba harus menerima vonis terkena HIV karena tertular dari suami mereka (Suriyani, 2006). Hal tersebut dapat memperburuk keadaan depresinya.

Beck (2009) dalam bukunya menjelaskan bahwa faktor penyebab depresi adalah adanya penyimpangan atau distorsi kognitif dari penderitanya. Terdapat pikiran-pikiran yang buruk mengenai dirinya, ditandai dengan adanya penilaian diri yang negatif dan harga diri yang rendah, memiliki harapan-harapan yang negatif. Cenderung menyalahkan dan mengkritik diri sendiri serta sulit untuk mengambil keputusan. Penderita depresi memiliki sikap pesimis yang disebabkan karena merasa tidak berharga, memiliki bayangan yang buruk tentang masa depannya dan sangat mengkhawatirkan adanya sebuah penolakan akibat perubahan yang dialaminya. Mereka berkeyakinan bahwa keadaan buruk yang dialaminya akan berlangsung terus menerus dan akan menjadi semakin buruk.
Hal ini selaras dengan yang disampaikan oleh Stuart \& Sundeen (2010) dalam Rahayu (2012) yang menyebutkan bahwa salah satu penyebab dari depresi adalah kurangnya rasa harga diri atau terjadinya harga diri rendah. Sebagian besar penderita HIV menghadapi problema rendah diri atau mempunyai gambaran diri yang negatif. Penelitian yang mendukung hal tersebut dilakukan oleh Rahayu (2012) di Poliklinik VCT RSUP Sanglah Denpasar. Hasil penelitian ini menunjukkan bahwa semakin tinggi harga diri yang dimiliki oleh penderita HIV maka tingkat depresi yang dialami semakin ringan. Namun sebaliknya semakin rendah harga diri yang dimiliki maka tingkat depresi yang dialami semakin berat. Penelitian lain yang mendukung dilakukan oleh Lewis, dkk pada tahun 2012. Hasil penelitian menyimpulkan bahwa kebanyakan responden menyalahkan diri sendiri, diikuti dengan perasaan kecil hati, hilangnya kesenangan, dan perasaan gagal pada kehidupannya, serta merasa sesuatu yang buruk terjadi pada dirinya (Lewis, Mosepele, Seloilwe, Lawler, 2012).

Penyimpangan kognitif lain yang dialami responden yaitu keluarga besarnya belum mengetahui status kesehatannya saat ini. Hal ini mengakibatkan responden merasa sangat tersiksa, karena sampai saat ini ia berusaha untuk menutupi statusnya tersebut. Ada rasa khawatir jika keluarga mengetahui keadaannya, ia akan di usir oleh keluarga besarnya, sedangkan suami yang selama ini memberinya suport, telah meninggal terlebih dahulu akibat HIV/AIDS yang dideritanya. Keadaan tersebut diakibatkan karena masih adanya stigma dan deskriminasi di masyarakat kepada penderita HIV yang sangat tinggi, sehingga lebih memperberat keadaan penderita HIV untuk dapat hidup secara layak dan normal di masyarakat (Chandra, 2006; Depkes, 2012; Rasmini, 2006).

Stigma dan diskriminatif yang dihubungkan dengan penyakit dapat menimbulkan efek psikologi yang berat bagi orang dengan HIV. Hal ini dalam beberapa kasus mendorong terjadinya depresi, kurangnya penghargaan diri dan keputusasaan (Rasmini, 2006). Hal ini selaras dengan penelitian yang dilakukan oleh Sarikusumah dan Nurhasanah (2012). Penelitian ini 
Reini Astuti: Pengaruh Intervensi SEFT terhadap Penurunan Tingkat Depresi Ibu Rumah Tangga

bertujuan untuk melihat gambaran pemaknaan subjektif konsep diri orang dengan HIV yang menerima label negatif dan diskriminasi dari lingkungan. Hasil penelitian tersebut menyimpulkan bahwa konsep diri penderita HIV sangat dipengaruhi oleh lingkungan sosialnya, penderita dengan HIV mengalami pelabelan negatif oleh lingkungan sosialnya (seperti mayat hidup, kutukan, aib), penderita mengalami berbagai bentuk diskriminasi (seperti dijauhi keluarga, pemisahan peralatan makan, dikucilkan oleh warga kampung dan lingkungan kerja), sehingga sebagai konsekuensi dari pemberian label negatif dan diskriminasi terbut, penderita HIV memandang, berpikiran, dan merasa negatif terhadap diri (seperti perasaan putus asa, depresi, tidak berharga, tidak berguna, tidak berdaya, menarik diri dari lingkungan, dan berkeinginan bunuh diri) (Sarikusumah dan Nurhasanah, 2012).

Mayoritas responden dalam penelitian ini menjawab bahwa merasa berkecil hati terhadap masa depannya. Hal ini sesuaidengan pernyataan Beck bahwa gejala kognitif yang diperlihatkan oleh seseorang dengan depresi yaitu memiliki harapan yang negatif, dimana ia akan memiliki sikap pesimis serta adanya keyakinan adanya bayangan buruk tentang masa depannya (Beck, 2009). Hawari (2006) juga menyebutkan bahwa penderita depresi memiliki sikap pesimis dalam menghadapi masa depannya (Hawari 2006). Selain itu menurut Cervone dan Pervin (2012) penderita depresi mengalami model cognitive triad (tiga pandangan negatif), salah satu diantaranya adalah adanya pandangan yang suram akan masa depannya (Cervone dan Pervin, 2012).

Sebagian ibu rumah tangga dengan HIV yang mengalami depresi menyatakan bahwa terkadang mereka mempunyai pikiran-pikiran untuk bunuh diri, walaupun tidak akan melaksanakannya. Hal tersebut sesuai dengan pernyataan Beck bahwa pada penderita HIV terdapat gejala motivasional yang pada keadaan terburuk dapat memiliki ide dan keinginan untuk mengakhiri hidup yang muncul baik secara pasif maupun aktif. Selain itu didukung pula oleh Hawari (2006) yang menyatakan bahwa di Amerika Serikat banyak penderita HIV yang mengalami depresi berkeinginan untuk melakukan bunuh diri. Katzenstein (1998) dalam Hawari (2006) menemukan bahwa 5\%-15\% dari penderita depresi melakukan bunuh diri setiap tahunnya. Hal ini sesuai dengan pernyataan Lam, Michalak, Swinson (2005) bahwa pada penderita depresi terdapat pikiran tentang kematian dan keinginan bunuh diri.

Temuan lain yang didapat dalam penelitian ini adalah sebagian besar ibu rumah tangga dengan HIV yang mengalami depresi memerlukan usaha yang lebih keras untuk memulai suatu pekerjaan, tidak dapat tidur nyenyak dan lebih merasa lelah daripada biasanya, terdapat penurunan selera makan sampai kehilangan berat badan 2,5 kg lebih dan merasa cemas dengan keadaan fisiknya yang sering merasa nyeri, sakit perut atau sembelit serta kurang berminat terhadap seks dibandingkan dengan biasanya. Hawari (2006) menyebutkan bahwa pada orang dengan depresi terdapat penurunan gairah hidup, tidak memiliki semangat hidup dan merasa tidak berdaya. Selain itu mengalami pula gangguan tidur, dapat berupa insomia atau sebaliknya hipersomnia, gangguan tidur ini dapat disertai dengan mimpi buruk. Penderita depresi kerap sekali merasa mudah lelah, lemah, lesu dan kurang energik. Selain itu nafsu makan menurun sehingga menyebabkan berat badan menurun, seringkali mengeluhkan sakit di berbagai tempat dalam tubuhnya (keluhan psikosomatik) dan terdapat gangguan fungsi seksual (terjadi penurunan libido) (Hawari, 2006). Hal tersebut didukung oleh penelitian yang dilakukan oleh Lewis, dkk (2012) yang menemukan bahwa wanita HIV positif yang mengalami depresi mengalami gejala somatik seperti perubahan nafsu makan (48\%), masalah tidur (47\%), dan kelelahan (47\%) serta terdapat responden yang melaporkan bahwa mereka mengalami hal yang buruk tentang diri mereka (40\%), kesulitan dalam berkonsentrasi (31\%) (Lewis, Mosepele, Seloilwe, Lawler, 2012). Lam, Michalak, Swinson, 2005) juga menyatakan bahwa penderita depresi mengalami juga kelelahan, perubahan psikomotor, gangguan tidur dan penurunan nafsu makan.

Tingkat Depresi setelah dilakukan Intervensi SEFT (Spiritual Emotional Freedom Technique) pada Kelompok Intervensi, hal ini selaras dengan Beck (2009) 
Reini Astuti: Pengaruh Intervensi SEFT terhadap Penurunan Tingkat Depresi Ibu Rumah Tangga

menyatakan bahwa depresi yang terjadi pada seseorang diakibatkan oleh adanya peyimpangan atau distorsi kognitif. Secara sistematis orang dengan depresi salah dalam mengevaluasi pengalaman-pengalaman masa lalu dan masa kininya, sehingga dia menganggap dirinya dan masa depannya negatif. Pada umumnya menurut konsep ini penderita akan memandang dan menganggap dirinya tidak sempurna, merasa tidak adekuat, tidak berguna dan cenderung menganggap pengalaman yang tidak menyenangkan sebagai suatu kekurangan mental atau sosial yang terdapat pada dirinya (Beck, 2009). Masalah-masalah pikiran, skema negatif dan kesalahan kognitif inilah yang menyebabkan depresi (Cervone dan Pervin, 2012). Sehingga Beck berpendapat bahwa, terapi yang tepat dalam menangani masalah depresi ini adalah dengan cara mengidentifikasikan dan mengkoreksi konseptualisasi atau pemikiranpemikiran yang terdistorsi serta mereposisi keyakinan-keyakinan yang disfungsional tersebut (Beck, 1993; Brewin, 1996 dalam Cervone dan Pervin, 2012).

Hal tersebut selaras dengan prinsip terapi yang terdapat di dalam SEFT (Spiritual Emotional Freedom Technique). Terapi ini memiliki prinsip dasar spiritual power yaitu yakin, ikhlas, pasrah, syukur dan khusyu (Zainudin, 2012). Ketika seseorang dalam keadaan yakin bahwa apa yang terjadi pada kehidupan ini adalah atas izin Allah SWT, dan semua kejadian dalam hidup ini adalah yang terbaik untuk dijalani. Yakin pada Maha kuasanya Allah SWT dan Maha sayangnya Allah pada mahluknya maka seseorang akan menjalani kehidupan ini dengan lebih tenang dan ringan (Zainudin, 2012). Gymnastiar (2008) menyatakan bahwa seseorang yang memiliki kayakinan akan pertolongan Allah SWT, maka pertolongan itu pasti datang, jika seseorang yakin bahwa kesulitannya akan dilapangkan oleh Allah SWT maka Dia akan melapangkannya, karena Allah SWT akan sesuai dengan prasangka hambanya (Gymnastiar, 2008). Keyakinan bahwa Allah SWT telah mengukur ujian yang menimpa termasuk penyakit yang ditimpakan pada seseorang, telah disesuaikan dengan kadar kemampuannya dan telah disesuai dengan kesanggupannya. Keyakinan bahwa setiap kesulitan selalu disertai dengan berbagai kemudahan yang diberikan Allah SWT (Gymnastiar, 2008) maka hal tersebut dapat memperbaiki penyimpangan kognitif yang terjadi pada penderita depresi.

Penelitian yang dilakukan oleh peneliti menemukan bahwa terdapat penurunan secara signifikan tingkat depresi pada kelompok intervensi setelah diberikan intervensi SEFT (Spiritual Emotional Freedom Technique). Penurunan tersebut terjadi dari tingkat depresi berat saat sebelum intervensi menjadi depresi sedang ketika telah diberikan intervensi, kemudian dari tingkat depresi sedang menjadi menjadi gangguan mood biasa, dan dari garis batas klinis depresi menjadi wajar atau normal. Bahkan ada salah satu responden yang mengalami depresi berat, setelah dilakukan intervensi tingkat depresinya menurun menjadi tingkat depresi wajar.

Beck (2009) bahwa seseorang dengan depresi mengalami juga disfungsi keyakinan akan pengalaman-pengalaman negatif, hal tersebut dapat di reposisi dengan keikhlasan seseorang dalam menjalani setiap episode kehidupannya. Ikhlas mengandung arti menerima semua ketentuan yang telah Allah tentukan untuk seseorang dengan sepenuh hati. Ikhlas juga mengandung arti tidak mengeluh, tidak pula menentang atas apa yang telah ditentukan olehNya. Zainudin menyebutkan bahwa yang membuat seseorang merasa berat menjalani kehidupannya lebih dikarenakan tidak mau menerima dengan ikhlas masalah yang ia hadapi. Ketika seseorang dapat mereposisi disfungsi keyakinannya tersebut dengan keikhlasan maka ikhlas tersebut menjadikan masalah menjadi sarana mensucikan diri dari dosa dan kesalahan yang pernah dilakukannya (Zainudin, 2012). Sentanu (2007) dalam bukunya tentang quantum ikhlas menyatakan bahwa ketika seseorang benar-benar berada dalam keikhlasan, saat itulah do'a atau niatnya melakukan kolaborasi dengan vibrasi energi quanta, sehingga melalui mekanisme kuantum yang tak terlihat, kekuatan Tuhanlah yang sebenarnya sedang bekerja. Inilah arti sebenarnya dari quantum ikhlas, sehingga ikhlas dapat membantu seseorang dalam menyelesaikan berbagai persoalan hidupnya (Sentanu, 2007). Pada kondisi hati yang ikhlas akan membuat seseorang menjadi 
Reini Astuti: Pengaruh Intervensi SEFT terhadap Penurunan Tingkat Depresi Ibu Rumah Tangga

tenang dan tahan dengan berbagai ujian, sehingga dapat menjadikan proses ikhtiar untuk mempertahankan kesehatannya lebih positif dan optimal (Gymnastiar, 2008).

Hal ini sesuai dengan penelitian yang dilakukan oleh Pargement, dkk yang meneliti tentang hubungan antara struggle of religious (ketahanan keagamaan) dengan kejadian penyakit dan risiko kematian pada lansia baik laki-laki maupun perempuan. Hasil penelitian menunjukkan bahwa para lansia yang memiliki masalah dengan agama cenderung mengalami peningkatan risiko kematian lebih besar walaupun telah dilakukan usaha untuk mengontrol kesehatan mereka baik fisik maupun mental. Sebaliknya mereka yang memiliki keyakinan agamanya yang baik memiliki kemungkinan memiliki umur yang lebih panjang (Pargament, Koenig, Tarakeshwar, Hahn, 2001).

Menurut Beck (2009) seseorang yang mengalami depresi mengalami juga disfungsi keyakinan terhadap masa depan dan kehidupan yang akan datang, hal ini dapat koreksi dengan sikap pasrah. Pasrah mengandung arti menyerahkan apa yang akan terjadi di masa datang hanya kepada Allah SWT. Pasrah bukan pula mengandung arti menyerah pada keadaan, akan tetapi pasrah yang sejati disertai dengan usaha yang optimal untuk mencari solusinya. Berusaha semaksimal mungkin sambil menyerahkan hasilnya kepada Allah SWT. Pasrah akan memberikan ketenangan dan kedamaian pada jiwa, karena keyakinan bahwa semua permasalahan yang dihadapi akan diselesaikan oleh Allah SWT (Zainudin, 2012).

Beck (2009) juga menyatakan bahwa seseorang dengan depresi akan mengalami disfungsi keyakinan tentang cara pandang yang menganggap bahwa dirinya tidak sempurna, merasa tidak adekuat, tidak berguna serta cenderung menganggap pengalaman yang tidak menyenangkan sebagai suatu kekurangan mental atau sosial, hal dapat di reposisi dengan rasa syukur dan khusyu. Syukur adalah rasa berterimakasih kepada Allah SWT atas semua yang telah diberikanNya. Bersyukur pada saat seseorang memiliki masalah atau dalam keadaan sakit memang tidak mudah, karena biasanya akan lebih fokus pada masalah yang dia hadapi sehingga lupa untuk melihat sisi positif lainnya. Padahal masih banyak nikmat lain yang dapat disyukuri ketika seseorang tidak hanya fokus memikirkan masalahnya. Keyakinan seseorang yang percaya bahwa Allah selalu memberikan yang terbaik dapat membuat seseorang menjadi lebih tenang. Hal ini akan lebih baik jika disertai dengan kekhusyuan dalam berdoa. Berdoa dan meminta kepada Allah SWT jalan terbaik dalam menyelesaikan masalah tersebut (Zainudin, 2012). Jika semua penjelasan di atas dapat dilakukan oleh ibu rumah tangga dengan HIV yang mengalami depresi, maka hal-hal tersebut membantu mengembalikan penyimpangan kognitif yang dialaminya sehingga depresi yang mereka alami dapat teratasi.

Terdapat perbedaan skor tingkat depresi pada kelompok intervensi dan kelompok kontrol setelah dilakukan SEFT (Spiritual Emotional Freedom Technique) pada kelompok intervensi. Hal ini disebabkan karena adanya lima prinsip utama SEFT (Spiritual Emotional Freedom Technique), yaitu syukur, ikhlas, sabar, yakin dan pasrah. Jika hal tersebut dapat di jalani dengan baik oleh ibu rumah tangga dengan HIV yang mengalami depresi, maka akan sangat membantu untuk menurunkan tingkat depresi. Hal tersebut dikarenakan kelima prinsip tersebut merupakan cara-cara yang dapat dilakukan untuk mereposisi distorsi kognitif atau difungsional keyakinan yang biasa terjadi pada orang dengan depresi (Cervone dan Pervin, 2012).

Keefektifan SEFT (Spiritual Emotional Freedom Technique) tidak hanya terletak pada Spiritual Power seperti yang telah dijelaskan sebelumnya di atas, akan tetapi SEFT merupakan gabungan antara Spiritual Power dengan Energy Psychology. Energy Psychology merupakan bidang ilmu yang relatif baru, namun prinsipnya sama dengan prinsip Energy Healing yang dikenal sejak lama di Tiongkok, Cina lebih dari 5000 tahun yang lalu. Energy Psychology adalah seperangkat prinsip dan teknik memanfaatkan sistem energi tubuh untuk memperbaiki kondisi pikiran, emosi dan perilaku(Freinstein dalam Zainudin, 2012). Ketidakseimbangan kimia dan gangguan energi dalam tubuh manusia turut berperan dalam timbulnya 
Reini Astuti: Pengaruh Intervensi SEFT terhadap Penurunan Tingkat Depresi Ibu Rumah Tangga

berbagai gangguan emosi, termasuk di dalamnya adalah depresi. Intervensi pada sistim energi tubuh dapat mengubah kondisi kimia di dalam otak (neurotransmitter) yang selanjutnya dapat mengubah kondisi emosi seseorang termasuk kondisi depresi (Zainudin, 2012). Setiap atom dalam sebuah benda termasuk manusia sebagai mahluk hidup memiliki energy electromagnetic yang mengalir di seluruh tubuhnya. Dokterdokter tiongkok menyakini bahwa salah satu energy yang berperan dalam kesehatan tubuh manusia adalah energy "Chi”.

Energy Chi mengalir di sepanjang 12 jalur yang disebut energy meridian, dan jika aliran energi ini terganggu maka akan menimbulkan masalah emosi (termasuk di dalamnya depresi) atau masalah fisik. Energy meridian ini dikenal juga dengan titik-titik akupuntur yang terdiri dari 361 titik dan di dalam SEFT kemudian lebih disederhanakan menjadi 18 titik. Hampir semua masalah emosi maupun fisik dapat di atasi dengan cara merangsang titik-titik tersebut (Zainudin, 2012). Cara merangsang titik-titik tersebut berbeda dengan akupuntur dan acupressure. Jika akupuntur menggunakan jarum dan acupressure menggunakan tekanantekanan yang kuat untuk merangsang titiktitik tersebut, maka SEFT menggunakan cara mengetuk ringan dengan ujung jari (disebut dengan istilah tapping) pada titiktitik energy meridian tersebut. Cara ini dapat membebaskan aliran energi di dalam tubuh penderita depresi sehingga dapat menurunkan tingkat depresinya. Kombinasi kedua hal tersebut yaitu spiritual power dan Energy Psychology sungguh sangat efektif dalam menurunkan tingkat depresi pada ibu rumah tangga dengan HIV.

Jika dilihat dari aspek reaksi fisiologis terhadap SEFT, maka perangsang dengan cara mengetuk-ngetuk ringan (tapping) pada titik 12 titik meridian tubuh tersebut dapat menstimulasi gland pituitary untuk mengeluarkan hormon endorphins (Johnson, 1999; Nopadow etc 2008 dalam Rokade, 2011), dimana hormon endorphins tersebut dapat memberikan efek menenangkan serta menimbulkan perasaan bahagia (Goldstein dan Lowry, 1975 dalam Rokade, 2011), sehingga dapat menurunkan tingkat depresi pada penderitanya. Titik-titik yang lebih spesifik dapat menurunkan tingkat depresi adalah titik Cr (Crown) yang terletak pada titik dibagian atas kepala, titik EB (Eye Brow) yaitu titik yang terletak pada titik permulaan alis mata dan titik IF (Index Finger) yaitu jari telunjuk di samping luar di bagian bawah kuku, di bagian yang menghadap ibu jari (Yinyanghouse, diunduh pada tanggal 20 November 2014).

Tidak terdapat perubahan tingkat depresi pada kelompok kontrol, bahkan cenderung mengalami sedikit peningkatan. Hal tersebut dikarenakan pada kelompok kontrol tidak diberikan intervensi SEFT seperti pada kelompok intervensi. Seseorang dengan depresi dan tidak segera ditangani akan menyebabkan penderitanya mengalami insomnia dan kelelahan. Depresi menyebabkan sulit tidur atau gangguan tidur yang dikenal sebagai insomnia. Hal ini dapat mengakibatkan kelelahan ekstrem yang menguras energi dan kesulitan dalam konsentrasi dan pengambilan keputusan (Wahyuningsih, 2011). Hawari (2006) juga menyatakan bahwa orang dengan depresi akan mengalami penurunan gairah hidup, merasa tidak berdaya dan tidak memiliki semangat hidup. Terdapat penurunan nafsu makan sehingga menyebabkan berat badan menurun (Hawari, 2006; Wahyuningsih 2011). Dampak lainnya adalah menarik diri (isolasi sosial). Kondisi depresi yang berkepanjangan tanpa penanganan, dapat menciptakan ketidakseimbangan serotonin, zat kimia penting dalam otak yang bertanggung jawab untuk membuat orang bahagia dan berjiwa sosial (Rokade, 2011).

\section{Simpulan}

Simpulan pada penelitian ini bahwa pada kelompok intervensi dan kelompok kontrol sebelum diberikan perlakuan SEFT (Spiritual Emotional Freedom Technique) mengalami depresi dari tingkat depresi pada batas garis klinis, depresi sedang sampai depresi berat. Pada kelompok intervensi setelah diberikan perlakuan SEFT mengalami penurunan tingkat depresi, sedangkan pada kelompok kontrol terdapat perubahan yang tidak begitu signifikan dan cenderung mengalami peningkatan. Terdapat perbedaan yang 
Reini Astuti: Pengaruh Intervensi SEFT terhadap Penurunan Tingkat Depresi Ibu Rumah Tangga

signifikan pada tingkat depresi ibu rumah tangga dengan HIV setelah dilakukan intervensi SEFT (Spiritual Emotional Freedom Technique).

\section{Daftar Pustaka}

Alemu, H., Haile, M. D., Tsui, A., Ahmed,S., \& Shewamare, A. (2011.). Effect of depressive symptoms and social support on weight and CD4 count increase at HIV clinic in Ethiopia. Psychology and Bahavioral Sciences Colletion,24, 866-876.

Beck, T. A., \& Alford, B. A. (2009). Depression: Causes and Treatment. Philadelphia: University of Pennsylvania. Diunduh dari http://books.google.co.id pada tanggal 22 Desember 2014.

Burack, J. H., Barrett, D. C., Stall, R. D., Chesney, M.A., Ekstrand, M.L., \& Coates, T. J. (1993). Depressive Symptoms and CD4 Lymphocyte decline among HIV infected men. US National Library of Medicine National Institutes of Health, 234-240.

Carter, M. (2011). Hubungan yang konsisten antara depresi dan kepatuhan yang rendah terhadap terapi HIV. Diunduh dari http://spiritia.or.id/news/bacanews. php?nwno=2696 pada bulan September 2014.

Cervone, D., \& Lawrence, P. (2012). Kepribadian: Teori dan Penelitian (Ed. 10). Jakarta: Penerbit Salemba Humanika.

Chandra, P.S., Desai, G., \& Rajan . (2005). $\mathrm{HIV}$ and psychiatric disorders. Indian Journal of Medical Research, 451-467.

Ciesla, J.A., \& Roberts, J. E. (2001). Metaanalysis of the relationship between HIV infection and risk for depressive disorders. American Journal of Psychiatry, 158(5), 725-730.

Darussalam. (2011). Analisa faktorfaktor yang berhubungan dengan depresi dan hopelessness pada pasien stroke di Blitar. Diunduh dari lontar.ui.ac.id/ file?file=digital $/ 20281857$.

Depkes RI, KPA Nasioal. ( 2007). execute summary trends of risky behaviors for HIV/ STI in Indonesia (Result of IBBS 2007). National Indonesian HIV/AIDS Research Inventory, 67-68.

Ditjen PP \& PL, Kemenkes. (2012). Laporan perkembangan HIV-AIDS di Indonesia, Triwulan III Tahun 2013. Jakarta: Kemenkes RI.

Feldman, R. S. ( 2011). Pengantar Psikologi: Understanding Psychology. (Ed 10). Jakarta: Penerbit Salemba Humanika.

Fernandez, F. M.D., \& Ruiz, P. M.D. (2006.). Psychiatric Aspects of HIV/AIDS. (1st ed.) New York: Lippincott William and Wilkins.

Gymnastiar, A . (2008). Menggapai derajat ihsan: Membangun pribadi mulia untuk meraih bahagia dunia dan akhirat. (Ed. 1). Bandung: Cahaya Iman.

Hawari, D. (2006a). Manajemen stres, cemas dan depresi. (Ed. 2). Jakarta: Balai Penerbit FKUI.

. D. (2006b). Global Efek HIV/AIDS dimensi psikoreligius. (Ed. 1). Jakarta: Balai Penerbit FKUI.

Ironson, G., Balbin, E., Stuetzle, R., Fletcher, M.A., O'Cleirigh, C., Laurenceau, J. P., Solomon G. (2005). Dispositional Optimism and the Mechanisms by Which It Predicts Slower Disease Progression in HIV: Proactive Behavior, Avoidant Coping, and Depression. International Journal of Behavioral Medicine Volume 12, 86-97.

KPA Nasional. (2009). HIV dan AIDS, Sekilas Pandang. (Ed. 2). Jakarta: Komisi Penanggulangan HIV/AIDS.

KPA Jawa Barat. (2013). Data HIV/AIDS Jawa Barat tahun 2012, Bandung: Komisi Penanggulangan HIV/AIDS Jawa Barat.

Lam,. R.W., Michalak, E. E,. \& Swinson, S. (2005). Assessment scales in depression, 
Reini Astuti: Pengaruh Intervensi SEFT terhadap Penurunan Tingkat Depresi Ibu Rumah Tangga

mania, and anxiety. London And New York: Taylor and Francis Group.

Lewis, E. L., Mosepele, M., Seloilwe, E., \& Lawler, K. (2012). Depression in HIVPositive Women in Gaborone, Botswana. Health Care for Women International, 375386.

Nursalam dan Kurniawati. (2009). Asuhan Keperawatan pada Pasien Terinfeksi HIV/ AIDS. Jakarta: Salemba Medika.

Ofovwe \& Ofovwe. (2013). Psychological Disorders among Human Immunodeficiency Virus-infected Adults in Southern Nigeria. African Journal of Reproductive Health, Volume, 17.

Pohan. (2009). Opportunistic Infection of HIV-Infected/AIDS Patients in Indonesia: Problems and Challenge. HIV/AIDS Research Inventory 1995-2009, 249-253.

Polit,. D. F., \& Beck, C. T. (2004). Nursing research principles and methods. (7th ed.). Philadelphia: Lippincott Williams And Wilkins.

Pyne, J.M., Asch, S. M., Lincourt, K., Kilbourne, A. M., Bowman C., Atkinson, H., ..Gifford, A. (2008). Quality Indicators for Depression Care in HIV Patients. AIDS Care, 1075-1083.

Rahayu, N. D. (2012). Hubungan Tingkat Harga Diri dengan Tingkat Depresi pada Klien Odha di Poliklinik Vct Rsup Sanglah Denpasar Tahun 2012. Diunduh dari http:// www.sanglahhospitalbali.com/v1/penelitian. php?ID=57 pada bulan September 2014 .

Rasmini, M. P. A. (2006). Lentera: Lembar tentang realita AIDS. Denpasar: Sloka Institute.

Rokade. (2011). Release of endomorphin hormone and its effects on our body and moods: A Review. International Conference on Chemical, Biological and Environment Sciences. Bangkok.
Sarikusuma, H., Hasanah, N., Herani, I. (2012.). Konsep Diri orang dengan HIV dan AIDS (ODHA) yang menerima label negatif dan diskriminasi dari lingkungan sosial. Psikologia-online,29-40.

Sentanu. (2007). Quantum ikhlas: Teknologi aktivasi kekuatan hati. Diunduh dari https:// books.google.co.id pada tanggal 20 Januari 2015.

Spiritia. (2008). Lembar informasi tentang HIV/AIDS untuk ODHA. Jakarta: Spiritia.

Supranto, J. (2000). Teknik sampling untuk survei dan eksperimen. Jakarta: Rineka Cipta.

Suriyani, L. D. (2007). Lentera (Lembar tentang Realita AIDS): Makin banyak ibu rumah tangga terinfeksi HIV(Ed.1). Denpasar: Sloka Institute.

Unnikrishnan, B., Jagganath, V,, Ramapuram, J. T., Achappa, B., \& Madi, D. (2012). Study of Depression and Its Associated Factors among Women Living with HIV/AIDS in Coastal South India. Diunduh dari http:// www.pubfacts.com. Dinduh pada tanggal 15 Januari 2015.

Wahyuningsih. (2011). Akibat jika orang depresi tidak disembuhkan. Diunduh dari www. Detik Health pada tanggal 16 Januari 2015.

Yaunin, Y., Afriant, R., \& Hidayat, N. M. (2014.). Kejadian Gangguan Depresi pada Penderita HIV/AIDS yang Mengunjungi poli VCT RSUP M. Jamil Padang Periode Januari-September 2013. Jurnal Kesehatan Andalas, 244-247.

Yinyang house, acupuncture points. Diunduh dari http://www.yinyanghouse.com/ acupuncturepoints/point_categories.

Zainudin, A. F. (2012). SEFT for Healing, Success Happines, Greatness(2nd ed.). Jakarta: Afzan Publishing. 